\title{
Monitoring of antioxidant activities with dried Gugija (Lycium chinensis Mill) extraction
}

\author{
Gee-Dong Lee* \\ Department of Food Science and Biotechnology, Joongbu University, Geumsan 32713, Korea
}

\section{건조 구기자의 추출에 따른 항산화 효능 모니터링}

\author{
이기동* \\ 중부대학교 식품생명과학과
}

\begin{abstract}
Thise study aimed to determine the optimum antioxidant extraction conditions of dried Gugija (Lycium chinensis Mill). To determine the operational parameters, including ethanol concentration $\left(X_{1}, 0 \sim 80 \%\right)$ and extraction time $\left(\mathrm{X}_{2}, 1 \sim 5 \mathrm{hr}\right)$, a response surface methodology was applied to monitor brown color intensity, total phenolic compounds, ABTS radical scavenging activity, and $\mathrm{Fe}^{2+}$ chelating activity. Coefficients of determinations $\left(\mathrm{R}^{2}\right)$ of the models were $0.8486 \sim 0.9214(p<0.05 \sim 0.1)$ in dependent parameters. Brown color intensity of Gugija extracts reached a maximum of 0.75 (OD in $420 \mathrm{~nm}$ ) under extraction conditions of $2.88 \mathrm{hr}$ in $78.10 \%$ ethanol. Total phenolic compounds reached a maximum of $2,355 \mu \mathrm{g}$ under extraction conditions of $4.94 \mathrm{hr}$ in $30.17 \%$ ethanol. ABTS radical scavenging activity was $13.83 \%$ at $4.61 \mathrm{hr}$ and $16.21 \%$ ethanol. $\mathrm{Fe}^{2+}$ chelating activity showed a maximum of $58.54 \%$ under extraction conditions of $3.39 \mathrm{hr}$ in $0.76 \%$ ethanol. Optimum extraction conditions (5 hr extraction in $15 \%$ ethanol) were obtained by superimposing the contour maps with regards to total phenolic compounds, ABTS radical scavenging activity, and $\mathrm{Fe}^{2+}$ chelating activity of dried Gugija. Maximum values of total phenolic compounds, ABTS radical scavenging activity, and $\mathrm{Fe}^{2+}$ chelating activity under optimum extraction condition were $2,397 \mu \mathrm{gg}, 15.62 \%$ and $54.78 \%$, respectively.
\end{abstract}

Key words : Lycium chinensis Mill, extraction, phenolic compounds, antioxidant activity, monitoring

\section{서 론}

구기자(Lycii fructus)는 전통적으로 한약재로 많이 이용 되어 왔으나 구기자차로도 널리 이용되어 온 건강식품 소재 이다. 최근 들어 구기자를 이용한 다양한 가공식품이 등장 하면서 구기자 관련 식품이 소비자들의 관심을 크게 끌고 있다.

구기자는 가지과에 속하는 다년생 식물의 열매로서 8월 부터 11 월까지 수확하므로 많은 양의 수확이 가능하며, 열

*Corresponding author. E-mail : geedlee@jbm.ac.kr Phone : 82-41-750-6291, Fax : 82-41-750-6160

Received 28 September 2016; Revised 1 November 2016; Accepted 3 November 2016.

Copyright (c) The Korean Society of Food Preservation. All rights reserved.
매뿐만 아니라 잎이나 뿌리도 건강식품이나 약재로 활용하 고 있어 농가 고소득 작목으로 재배되고 있다(1).

구기자 열매의 주요 성분으로는 betaine, rutin, kukoamine, $\rho$-coumaric acid, cerebroside, carotenoid, $\beta$-sitosterol, zeaxanthin, physalien, cholin 등 $(2,3)$ 이 있으며, 미량의 특수 성분으로는 stigmasterol, campesterol, cholesterol, cycloeucalenol, obtusifoliol, gramisterol, citrostadienol, cycloartanol, taurine, y-aminobutric acid 등(3) 다양한 성분이 발견되어 각종 phytochemicals가 풍부하게 함유되어 있는 것으로 알려져 있다. 그리고 구기자의 잎에도 페놀성 화합물이 많이 들어 있는데, quercetin-rhamno-di-hexoside, quercetin-3-O-rutinoside, dicaffeoylquinic acid isomers, chlorogenic acid, quercetindi-(rhamnohexoside), kaempferol-3-O-rutinoside, isorhamnetin3-O-rutinoside, $\rho$-coumaric acid, caffeic acid, vanillic acid 등이 존재하는 것으로 밝혀져 있다(3). 
전통적으로 장수식품으로 전해 내려온 구기자의 항산화 성에 대한 연구는 최근 들어 많이 이루어져 왔다. 구기자 추출물의 DPPH 라디칼 소거능은 물 추출물이 에탄올 추출 물 보다 높게 나타났으며, 페놀성 화합물인 chlorogenic acid 함량 또한 물 추출물이 에탄올 추출물보다 더 많은 것으로 보고되었다(4). 구기자 추출물의 ABTS 라디칼 소거능은 물 추출물이 에탄올 추출물 보다 높아서 $\mathrm{DPPH}$ 와 유사한 것으로 보고되어 있으며(4), 구기자 추출용매별 항산화 효 과는 메탄올 추출물의 항산화 효과가 가장 높았으며, 다음 으로 에탄올 추출물이 높은 것으로 보고되었다(5). 구기자 분말을 유과 및 매작과에 첨가한 연구에서 매작과에서는 항산화 효과가 나타나지 않고 오히려 구기자 분말을 많이 넣을수록 과산화가 더 빨리 진행되었으나, 구기자 분말 $5 \%$ 을 넣은 유과에서는 과산화물가가 상대적으로 낮은 것으로 보고되었다(6). 구기자를 이용하여 만든 맥주는 일반 맥주 보다 SOD활성이 더 높게 나타났고(7), 구기자 맥주 섭취가 흰쥐의 항산화 효소의 활성을 높여 간조직내 지질과산화물 함량이 일반 맥주 섭취군에 비해 상대적으로 낮은 것으로 보고되었다(8).

항산화성 측정으로서 널리 사용되고 있는 방법으로 $\mathrm{DPPH}$ 라디칼 소거능, $\mathrm{ABTS}$ 라디칼 소거능, SOD 활성 등 을 들 수 있는데, 이 중에서 $\mathrm{ABTS}$ 라디칼 소거능은 DPPH 라디칼 소거능과 같이 수소를 공여하는 항산화 물질의 항산 화 효과를 측정하는데 효과적으로 사용되고 있으며, 또한 $\mathrm{DPPH}$ 라디칼 소거능과는 달리 chain breaking 항산화물질 의 항산화 효능을 동시에 측정할 수 있는 특징을 가지고 있으므로 다양한 항산화 물질의 항산화 효능을 측정하기 적합한 것으로 알려져 있다(9).

따라서 본 연구에서는 건조 구기자의 항산화 성분과 항
산화 효과를 연구하고자 구기자의 추출조건을 최적화 하고 그 특성을 모니터링 하였다.

\section{재료 및 방법}

\section{실험재료 및 시약}

본 실험에 사용된 구기자(Lycium chinensis Mill)는 충남 청양군 청양구기자농협에서에서 건조 구기자를 구입하여 시료로 사용하였다. 구기자의 전처리는 건조구기자를 분쇄 기(삼성제약기계, Seoul, Korea)로 마쇄하여 20 40 mesh 분 말을 추출시료로 사용하였다. 그 외 시약은 Folin-Ciocalteu reagent(Sigma-Aldrich, St. Louis, MO, USA), ABTS[2,2-azino-bis(3-ethylbenzo-thiazoline-6-sulfonic acid)](Sigma-Aldrich, USA), gallic acid (Sigma, USA), ferrozine(Sigma-Aldrich, USA) 을 사용하였다. 시료의 흡광도 측정은 분광광도계(UVspectrophotometer UV1601, Shimadzu, Kyoto, Japan)를 이용 하여 측정하였다.

\section{추줄조건}

추출 조건은 환류냉각기에 부착한 $250 \mathrm{~mL}$ 등근플라스크 에 구기자분말 $20 \mathrm{~g}$ 과 추출용매 $200 \mathrm{~mL}$ 를 넣고 $70^{\circ} \mathrm{C}$ 에서 일정 시간 추출하였다. 이 때 추출용매의 에탄올 농도와 추출 시간은 중심합성실험계획에 따라 설정하였다.

\section{실험계획 및 반응표면분석}

건조 구기자의 추출조건에 따른 항산화 성분과 $\mathrm{ABTS}$ 라디칼 소거능 등 항산화성의 변화를 모니터링하고자 실험 계획은 중심합성계획법(10)에 의하여 설계하였고, 반응표

Table 1 . Experimental data on brown color intensity, total phenolic compounds, ABTS radical scavenging activity and $\mathrm{Fe}^{2+}$ chelating activity of the dried Gugija (Lycium chinensis Mill) under different conditions based on central composite design for response surface analysis

\begin{tabular}{ccccccc}
\hline & \multicolumn{2}{c}{ Extraction conditions } & Brown color intensity \\
Exp. No. ${ }^{1)}$ & $\begin{array}{c}\text { Ethanol conc. } \\
(\%)\end{array}$ & $\begin{array}{c}\text { Extraction time } \\
(\mathrm{hr})\end{array}$ & $\begin{array}{c}\text { Total phenolic } \\
\text { compounds } \\
(\mu \mathrm{g} / 100 \mathrm{~g})\end{array}$ & $\begin{array}{c}\text { ABTS radical } \\
\text { scavenging activity } \\
(\%)\end{array}$ \\
\hline 1 & $60(1)$ & $4(1)$ & $0.803^{2)}$ & 1,634 & 6.88 & 29.87 \\
$\mathrm{Fe}^{2+}$ chelating activity (\%)
\end{tabular}

${ }^{1)}$ The number of experimental conditions by central composite design.

${ }^{2)}$ Data were expressed as mean of triplicate determinations. 
면 회귀분석을 위해서는 SAS program(Statistical Analysis System, ver. 8.01, SAS Institute Inc., Cary, NC, USA)을 사용하였다.

중심합성실험계획에 따라 추출용매로서 에탄올의 농도 $(0,20,40,60,80 \%)$ 및 추출 시간 $(1,2,3,4,5 \mathrm{hr})$ 은 -2 , $-1,0,1,2$ 다섯 단계로 부호화 하였으며, 실험계획은 Table 1 에 나타내었다. 종속변수로는 갈색도, 총 페놀성 화합물, $\mathrm{ABTS}$ 라디칼 소거능 및 $\mathrm{Fe}^{2+}$ chelating activity로 하였다.

\section{갈색도 측정}

갈색도를 측정하기 위한 건조 구기자 추출물은 건조 구 기자 시료 대비 8 배 희석하여 갈색도 측정용 시험용액으로 사용하였다. 갈색도의 측정은 분광광도계(UV-spectrophotometer UV1601, Shimadzu, Kyoto, Japan)를 사용하여 $420 \mathrm{~nm}$ 에서 흡광도를 측정하였다.

\section{총 페놀성 화합물 함량 측정}

페놀성 화합물의 함량은 gallic acid를 표준물질로 하여 Folin-Ciocalteu reagent 발색법(11)으로 분석하였다. 분석시 험은 $\mathrm{Na}_{2} \mathrm{CO}_{3}(20 \mathrm{~g} / 100 \mathrm{~mL}) 1.5 \mathrm{~mL}$, Folin-Ciocalteu reagent $500 \mu \mathrm{L}$, DIW(deionized water) $6 \mathrm{~mL}$, 시험용액 $100 \mu \mathrm{L}$ 를 혼합한 후 상온에서 2시간 반응시킨 후 $765 \mathrm{~nm}$ 에서 흡광도 를 측정하였다. 표준물질의 제조는 gallic acid를 DIW에 용 해하여 $100 \mathrm{mg} / 100 \mathrm{~mL}$ 으로 만든 후 DIW로 희석하여 검량 곡선을 작성 후 시료 $100 \mathrm{~g}$ 중 $\mu \mathrm{g}$ gallic acid로 나타내었다.

\section{ABTS 라디칼 소거능 측정}

ABTS[2,2-azino-bis-(3-ethylbenzo-thiazoline-6-sulfonic acid)] radical 소거능은 ABTS radical cation decolorization $\operatorname{assay(12)ㄹㅡㄹ~ㅇㅣㅇㅛㅇㅎㅏㅇㅕ~ㅊㅡㄱㅈㅓㅇㅎㅏㅇㅕㅆㄷㅏ.~} 7.4 \mathrm{mM} \mathrm{ABTS}$ 용액과 $2.6 \mathrm{mM}$ potassium persulphate를 혼합하여 실온의 암소에서 하루 동안 방치하여 양이온(ABTS $\left.{ }^{+}\right)$을 형성시킨 다음, phosphate buffered saline(PBS, pH 7.4)로 희석하여 $734 \mathrm{~nm}$ 에서 흡광도 값이 1.0 이하가 되도록 하였다. 희석된 $\mathrm{ABTS}^{+}{ }^{+}$용액 $150 \mu \mathrm{L}$ 와 건조 구기자 시료 대비 20배 추출 및 희석된 시료를 각각 $5 \mu \mathrm{L}$ 씩 혼합하여 실온에서 10 분간 반응시킨 후 $734 \mathrm{~nm}$ 에서 흡광도를 측정하였다. ABTS 라디 칼 소거능(\%)은 1 에서 시료 첨가구의 흡광도를 시료 무첨가 구의 흡광도로 나눈 수치를 뺀 후 100 을 곱하여 나타내었다.
$\mathrm{Fe}^{2+}$ chelating activity 측정

$\mathrm{Fe}^{2+}$ chelating activity는 Hus 등(13)의 방법에 의해 측정 하였다. $2 \mathrm{mM} \mathrm{FeCl}_{2} 60 \mu \mathrm{L}$, 건조구기자 시료 대비 50배 추출 및 희석된 시료 $40 \mu \mathrm{L}$ 및 증류수 $700 \mu \mathrm{L}$ 를 혼합한 후 상온에서 약 10 분간 반응시켰다. 반응 후 $5 \mathrm{mM}$ ferrozine $40 \mu \mathrm{L}$ 를 첨가하여 $\mathrm{Fe}^{2+}$-ferrozine complex를 유도하기 위해 상온에서 약 5 분간 다시 반응시켰다. 반응 후 $562 \mathrm{~nm}$ 에서 흡광도를 측정하였다. $\mathrm{Fe}^{2+}$ chelating activity (\%)은 1에서 시료 첨가구의 흡광도를 시료 무첨가구의 흡광도로 나눈 수치를 뺀 후 100 을 곱하여 나타내었다.

\section{결과 및 고찰}

\section{갈색도의 변화}

건조 구기자의 추출에 따른 갈색도의 변화를 관찰해 본 결과, 에탄올 농도 및 추출 시간의 변화에 따른 갈색도의 변화는 0.42 0.80(420 nm에서 흡광도)의 차이를 나타내었 다(Table 1). 이를 회귀분석한 결과 갈색도에 대한 모델식의 $\mathrm{R}^{2}$ 은 0.8903 으로 $5 \%$ 이내 유의수준에서 유의성이 있었다 (Table 2).

건조 구기자의 추출에 따른 갈색도는 에탄올 농도가 증 가할수록 비례적으로 증가하는 경향을 나타내었으며, 추출 시간의 변화에 따른 수율의 변화는 크지 않았으나 에탄올 농도 $50 \%$ 이하에서는 추출 시간이 증가할수록 증가하는 경향을 나타내었다. 그러나 에탄올 농도 $60 \%$ 이상에서 고 온 장시간 추출시 다소 감소하는 경향을 나타내었다(Fig. 1). 이러한 현상은 높은 에탄올 농도에서 고온 장시간 추출 로 갈색도에 영향을 주는 색소가 변화되기 때문으로 여겨진 다. 추출 변수인 에탄올 농도와 추출 시간이 갈색도에 미치 는 영향을 알아보고자 회귀분석을 통해 $\mathrm{F}$ 값을 구해 본 결과 (Table 3), 에탄올 농도의 영향이 가장 높게 나타나 F값이 10.28 으로 $10 \%$ 의 유의수준에서 유의성이 인정되었으나, 추출 시간의 영향은 낮게 나타나 $\mathrm{F}$ 값이 0.83 로 유의성이 인정되지 않았다.

건조 구기자의 갈색도에 대한 반응표면 형태는 최대점을 나타내었으며, 최소의 수율은 에탄올 농도 $2.37 \%$, 추출 시 간 $2.32 \mathrm{hr}$ 에서 0.37 을 나타내었다. 그러나 최대의 갈색도는 에탄올 농도 $78.10 \%$, 추출 시간 $2.38 \mathrm{hr}$ 에서 0.75 을 나타내

Table 2. Polynomial equations calculated by RSM program for the dried Gugija

\begin{tabular}{cccc}
\hline Responses & Polynomial equations ${ }^{1)}$ & $\mathrm{R}^{2}$ & Signifi-cance \\
\hline Brown color intensity & $\mathrm{Y}_{1}=0.126595+0.012201 \mathrm{X}_{1}+0.118702 \mathrm{X}_{2}-0.000937 \mathrm{X}_{1} \mathrm{X}_{2}-0.000061786 \mathrm{X}_{1}^{2}-0.009964 \mathrm{X}_{2}^{2}$ & 0.8903 & 0.0470 \\
Total phenolic compounds & $\mathrm{Y}_{4}=1226.98+48.945833 \mathrm{X}_{1}-166.291667 \mathrm{X}_{2}-5.8625 \mathrm{X}_{1} \mathrm{X}_{2}-0.405156 \mathrm{X}_{1}^{2}+70.3125 \mathrm{X}_{2}^{2}$ & 0.8667 & 0.0676 \\
ABTS radical scavenging activity & $\mathrm{Y}_{6}=0.998512+0.19881 \mathrm{X}_{1}+1.917619 \mathrm{X}_{2}-0.067375 \mathrm{X}_{1} \mathrm{X}_{2}-0.000449 \mathrm{X}_{1}^{2}+0.280536 \mathrm{X}_{2}^{2}$ & 0.8486 & 0.0856 \\
$\mathrm{Fe}^{2+}$ chelating activity & $\mathrm{Y}_{7}=50.32003-0.338351 \mathrm{X}_{1}+3.186964 \mathrm{X}_{2}-0.03825 \mathrm{X}_{1} \mathrm{X}_{2}+0.000757 \mathrm{X}_{1}^{2}-0.193661 \mathrm{X}_{2}^{2}$ & 0.9214 & 0.0249 \\
\hline
\end{tabular}

${ }^{1)} \mathrm{X}_{1}$, Ethanol conc (\%); $\mathrm{X}_{2}$, Extraction time (hr). 


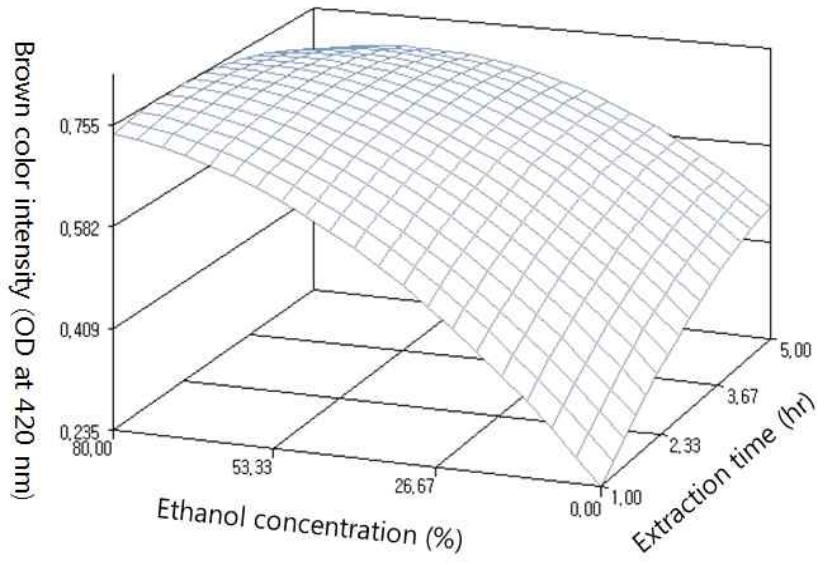

Fig. 1. Response surface for brown color intensity of the dried Gugija as a function of extraction ethanol concentration and time.

Table 3. Regression analysis for regression model of brown color intensity, total phenolic compounds, ABTS radical scavenging activity and $\mathrm{Fe}^{2+}$ chelating activity of the dried Gugija

\begin{tabular}{ccc}
\hline \multirow{2}{*}{ Regression model } & \multicolumn{2}{c}{ F-value } \\
\cline { 2 - 3 } & Ethanol conc. & Extraction time \\
\hline $\mathrm{Y}_{\text {Brown color intensity }}$ & $10.28^{* * 1)}$ & 0.83 \\
$\mathrm{Y}_{\text {Total phenolic compounds }}$ & $4.40^{*}$ & 1.26 \\
$\mathrm{Y}_{\text {ABTS radical scavenging activity }}$ & 4.06 & $4.93^{*}$ \\
$\mathrm{Y}_{\text {Fe2+ chelating activity }}$ & $15.54^{* *}$ & 0.11 \\
\hline
\end{tabular}

${ }^{1)^{*}}$ Significant at $10 \%$ level; ${ }^{* *}$ Significant at $5 \%$ level.

었다(Table 4). 건조 및 추출 중 형성된 갈색물질은 주로 Maillard 반응에 의해 형성된 멜라노이딘으로서 고농도의 에탄올 용액에 용해되지 않는다. 따라서 건조 구기자의 갈 색물질은 구기자 고유의 색소가 대부분인 것으로 여겨진 다.

\section{총 페놀 화합물의 변화}

건조 구기자의 추출에 따른 총 페놀성 화합물의 변화를 관찰해 본 결과, 총 페놀성 화합물의 함량이 시료 $100 \mathrm{~g}$ 당 1,296 2,318 $\mu \mathrm{g}$ 으로 에탄올 농도와 추출 시간에 따라 큰
차이를 타나내었다(Table 1). 이를 회귀분석한 결과, 총 페놀성 화합물의 $\mathrm{R}^{2}$ 은 각각 0.8667 로 $10 \%$ 이내 유의수준에 서 유의성이 있었다(Table 2).

건조 구기자의 총 페놀성 화합물의 함량은 1 시간 추출에 서 에탄올 농도가 증가할수록 증가하는 경향을 나타내었 다. 그러나 $60 \%$ 이상의 높은 에탄올 농도에서는 다소 감소 하는 경향을 나타내었다. 그리고 에탄올 농도 $20 \%$ 이하에 서는 추출 시간이 증가할수록 증가하는 경향을 나타내었 다. 그러나 에탄올 함량이 $50 \%$ 이상에서는 추출 시간이 증가할수록 페놀성 화합물의 함량이 급격히 줄어드는 것을 볼 수 있었다(Fig. 2). 이러한 현상은 높은 에탄올 농도에서 고온 장시간 추출시 페놀성 화합물이 불용화되거나 분해되 는 것으로 여겨진다. 그러나 $30 \%$ 이하의 낮은 에탄올 농도 에서는 시간이 경과할수록 페놀성 화합물이 증가하는 경향 이었는데, 이것은 Cho 등(4)이 구기자의 페놀성 화합물인 protocatechuic acid, caffeic acid, chlorogenic acid courmaric acid 등이 $60 \%$ 에탄올 추출물보다 물 추출물에서 더 많이 추출된다고 한 내용과 일치하는 경향을 보였다. 에탄올 농 도와 추출 시간이 총 페놀성 화합물의 변화에 미치는 영향 을 알아보고자 회귀분석을 통해 F값을 구해 본 결과(Table $3)$, 에탄올 농도의 영향이 높게 나타나 F값이 4.40 이었으나,

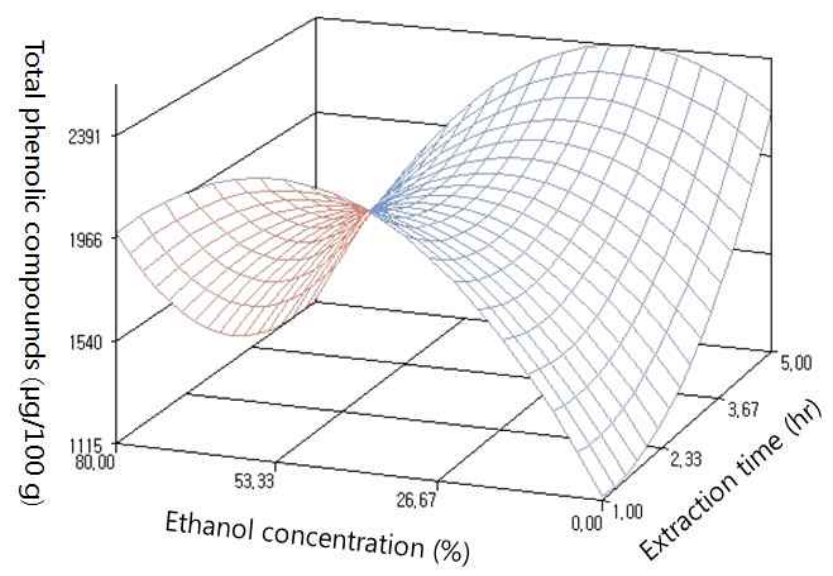

Fig. 2. Response surface for total phenolic compounds of the dried Gugija as a function of extraction ethanol concentration and time.

Table 4. Estimated levels of optimum extraction conditions for antioxidative activity of the dried Gugija

\begin{tabular}{|c|c|c|c|c|c|c|c|}
\hline \multirow{3}{*}{ Responses } & \multicolumn{4}{|c|}{ Extraction conditions } & \multirow{2}{*}{\multicolumn{2}{|c|}{ Estimated responses }} & \multirow{3}{*}{ Morphology } \\
\hline & \multicolumn{2}{|c|}{$\begin{array}{c}\text { Ethanol conc. } \\
(\%)\end{array}$} & \multicolumn{2}{|c|}{$\begin{array}{l}\text { Extraction time } \\
\text { (hr) }\end{array}$} & & & \\
\hline & Max. & Min. & Max. & Min. & Max. & Min. & \\
\hline Brown color intensity (OD at $420 \mathrm{~nm}$ ) & 78.1 & 2.37 & 2.38 & 2.32 & 0.75 & 0.37 & Maximum \\
\hline Total phenolic compounds $(\mu \mathrm{g} / 100 \mathrm{~g})$ & 30.17 & 79.12 & 4.94 & 3.42 & 2,355 & 1,231 & Saddle point \\
\hline ABTS radical scavenging activity (\%) & 16.21 & 76.62 & 4.61 & 3.81 & 13.83 & 5.31 & Saddle point \\
\hline $\mathrm{Fe}^{2+}$ chelating activity $(\%)$ & 0.76 & 79.55 & 3.39 & 3.30 & 58.54 & 25.41 & Saddle point \\
\hline
\end{tabular}


Table 5. Experimental values of response variables at the given extraction conditions within the response surfaces

\begin{tabular}{|c|c|c|c|c|c|}
\hline \multicolumn{2}{|c|}{ Extraction conditions ${ }^{1)}$} & \multirow{2}{*}{$\begin{array}{l}\text { Brown color intensity } \\
\text { (OD at } 420 \mathrm{~nm})\end{array}$} & \multirow{2}{*}{$\begin{array}{l}\text { Total phenolic compounds } \\
(\mu \mathrm{g} / 100 \mathrm{~g})\end{array}$} & \multirow{2}{*}{$\begin{array}{l}\text { ABTS radical scavenging } \\
\text { activity }(\%)\end{array}$} & \multirow{2}{*}{$\mathrm{Fe}^{2+}$ chelating activity (\%) } \\
\hline $\begin{array}{l}\text { Ethanol conc. } \\
\qquad \%)\end{array}$ & $\begin{array}{c}\text { Extraction time } \\
\text { (hr) }\end{array}$ & & & & \\
\hline 0 & 1 & 0.2754 & 1,293 & 4.77 & 43.82 \\
\hline $15 \%$ & 5 & 0.5492 & 2,397 & 15.62 & 54.78 \\
\hline
\end{tabular}

${ }^{1)}$ Optimum extraction condition ( $5 \mathrm{hr}$ at $150 \%$ ethanol) by the response surface methodology and basic condition $(1 \mathrm{hr}$ at water).

추출 시간의 영향은 상대적으로 낮게 나타나 F값이 1.26 으 로 조건 변수 모두 유의성이 인정되지 않았다.

건조 구기자의 총 페놀성 화합물에 대한 반응표면 형태 는 안장점(saddle point)을 나타내었으며, 최소의 총 페놀성 화합물은 에탄올 농도 $79.12 \%$, 추출 시간 $3.42 \mathrm{hr}$ 에서 1,231 $\mu \mathrm{g}$ 를 나타내었다. 그러나 최대의 총 페놀성 화합물은 에탄 올 농도 $30.17 \%$, 추출 시간 $4.94 \mathrm{hr}$ 에서 $2,355 \mu \mathrm{g}$ 를 나타내었 다(Table 4). 건조 구기자의 총 페놀 화합물의 추출을 위해서 는 $30 \%$ 의 에탄올로 5 시간 정도 추출하는 것이 더 많은 총 페놀성 화합물을 얻을 수 있는 것으로 여겨진다.

\section{ABTS 라디칼 소거능의 변화}

건조 구기자의 추출에 따른 $\mathrm{ABTS}$ 라디칼 소거능 변화를 관찰해 본 결과, 시료 대비 20배 희석된 시험용액의 $\mathrm{ABTS}$ 라디칼 소거능이 6.88 12.85\%로 에탄올 농도와 추출 시간 에 따라 차이를 타나내었다(Table 1). 이를 회귀분석한 결과 $\mathrm{ABTS}$ 라디칼 소거능의 $\mathrm{R}^{2}$ 은 각각 0.8486 로 $10 \%$ 이내 유의 수준에서 유의성이 있었다(Table 2).

건조 구기자의 $\mathrm{ABTS}$ 라디칼 소거능 변화는 총 페놀성 화합물 함량과 유사한 반응표면을 나타내었다. 추출 시간 1 시간에서는 에탄올 농도가 증가할수록 비례적으로 증가 하는 경향을 나타내었으며, 에탄올 농도 $50 \%$ 까지는 추출 시간 또한 증가할수록 크게 증가하는 경향을 나타내었다 (Fig. 3). 그러나 총 페놀성 화합물과 마찬가지로 에탄올 농도 $60 \%$ 이상에서는 추출 시간이 경과할수록 서서히 감소 하는 경향을 나타내었다(Fig. 3). ABTS 라디칼 소거능은 총 페놀성 화합물의 영향을 크게 받는 것으로 여겨지며, 페놀성 화합물이 ABTS 라디칼 소거능을 나타내는 주요 항산화 성분으로 여겨진다. 충분한 시간 동안 추출할 경우 에는 물 또는 낮은 에탄올 농도에서 추출한 추출물이 ABTS 라디칼 소거능이 가장 높은 반응표면을 형성하였는데, 이 것은 Cho 등(4)이 구기자 추출물의 ABTS 라디칼 소거능이 $60 \%$ 에탄올 추출물보다 물 추출물이 더 높다는 연구 결과 와 일치하였다. 에탄올 농도와 추출 시간이 $\mathrm{ABTS}$ 라디칼 소거능 변화에 미치는 영향을 알아보고자 회귀분석을 통해 $\mathrm{F}$ 값을 구해 본 결과(Table 3), 에탄올 농도의 영향이 상대적 으로 낮게 나타나 F값이 4.06으로 유의성이 인정되지 않았 으나, 추출 시간의 영향은 낮게 나타나 F값이 4.93 로 $10 \%$ 의 유의수준에서 유의성이 인정되었다.

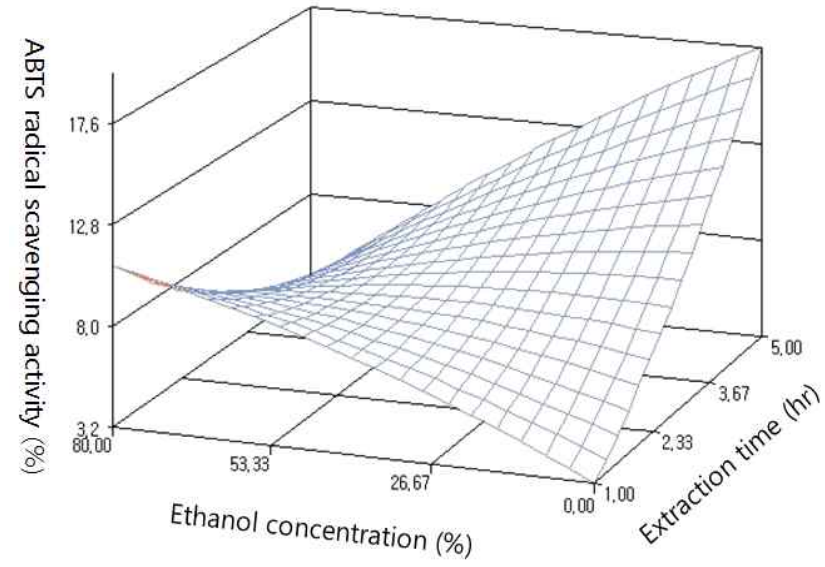

Fig. 3. Response surface for ABTS radical scavenging activity of the dried Gugija as a function of extraction ethanol concentration and time.

건조 구기자의 ABTS 라디칼 소거능에 대한 반응표면은 안장점(saddle point)의 형태를 나타내었으며, 최소의 ABTS 라디칼 소거능은 에탄올 농도 $76.62 \%$, 추출 시간 $3.81 \mathrm{hr}$ 에 서 $5.31 \%$ 를 나타내었다. 그러나 최대의 $\mathrm{ABTS}$ 라디칼 소거 능은 에탄올 농도 $16.21 \%$, 추출 시간 $4.61 \mathrm{hr}$ 에서 $13.83 \%$ 를 나타내었다(Table 4). 최대 ABTS 라디칼 소거능이 낮게 나타났지만 시료 대비 20 배 희석된 시험용액의 ABTS 라디 칼 소거능임을 감안한다면 아주 높은 항산화 효과를 나타내 었음을 알 수 있다. ABTS 라디칼 소거능이 총 페놀성 화합 물의 추출조건인 낮은 에탄올 농도에서 긴 시간 추출할 경우 높게 나타나는 패턴과 일치하고 있어 총 페놀성 화합 물이 ABTS 라디칼 소거능에 영향을 미치는 중요한 항산화 성분으로 여겨진다. 따라서 에탄올 농도 10 30\%에서 4 5 시간 추출하는 것이 항산화 효과가 높은 페놀성 화합물 등을 항산화 성분을 많이 추출할 수 있을 것으로 판단된다.

$\mathrm{Fe}^{2+}$ chelating activity의 변화

건조 구기자의 항산화 효과를 모니터링하고자 에탄올 농도 및 추출 시간에 따른 $\mathrm{Fe}^{2+}$ chelating activity의 변화를 관찰해 본 결과, 시료 대비 50 배로 추출 및 희석한 구기자 추출물의 $\mathrm{Fe}^{2+}$ chelating activity는 27.40 59.36\%로 에탄올 농도에 따라 큰 차이를 타나내었다(Table 1). 이를 회귀분석 한 결과 $\mathrm{Fe}^{2+}$ chelating activity의 $\mathrm{R}^{2}$ 은 각각 0.9214 로 $5 \%$ 
이내 유의수준에서 유의성이 있었다(Table 2).

건조 구기자의 $\mathrm{Fe}^{2+}$ chelating activity는 에탄올 농도가 증가할수록 급격히 감소하고 추출 시간이 증가함에 따라 다소 증가하는 반응표면 패턴을 나타내었다(Fig. 4). $\mathrm{Fe}^{2+}$ chelating activity는 에탄올 함량이 적은 조건에서 추출되는 수용성 성분으로 추측할 수 있으나, 갈변물질과는 완전히 정 반대의 반응표면을 나타내고 있으며, 총 페놀성 화합물 의 반응표면과도 다른 패턴을 보여 갈변물질이나 페놀성 화합물의 영향은 아주 낮으며, lactic acid, malic acid, oxalic acid 등(14) 구기자 유래 유기산이 킬레이트 활성에 크게 관여하는 것으로 여겨진다. 에탄올 농도와 추출 시간이 $\mathrm{Fe}^{2+}$ chelating activity의 변화에 미치는 영향을 알아보고자 회귀 분석을 통해 $\mathrm{F}$ 값을 구해 본 결과(Table 3), 에탄올 농도의 영향이 상대적으로 높게 나타나 $\mathrm{F}$ 값이 15.54 으로 $5 \%$ 의 유 의수준에서 유의성이 인정되었으나, 추출 시간의 영향은 낮게 나타나 F값이 0.11로 유의성이 인정되지 않았다.

건조 구기자의 $\mathrm{Fe}^{2+}$ chelating activity에 대한 반응표면은 안장점(saddle point)의 형태를 나타내었으며, 최소의 $\mathrm{Fe}^{2+}$ chelating activity는 에탄올 농도 $79.55 \%$, 추출 시간 3.30 $\mathrm{hr}$ 에서 $25.41 \%$ 를 나타내었다. 그러나 최대의 $\mathrm{Fe}^{2+}$ chelating activity는 에탄올 농도 $0.76 \%$, 추출 시간 $3.39 \mathrm{hr}$ 에서 $58.54 \%$ 를 나타내었다(Table 4). 최대점에서의 $\mathrm{Fe}^{2+}$ chelating activity가 58.54\%로 상대적으로 크지 않으나 사용된 시험 용액이 시료 대비 50 배나 희석한 시험용액을 사용하여 측 정된 수치이므로 chelating activity가 아주 크게 나타났음을 알 수 있다.

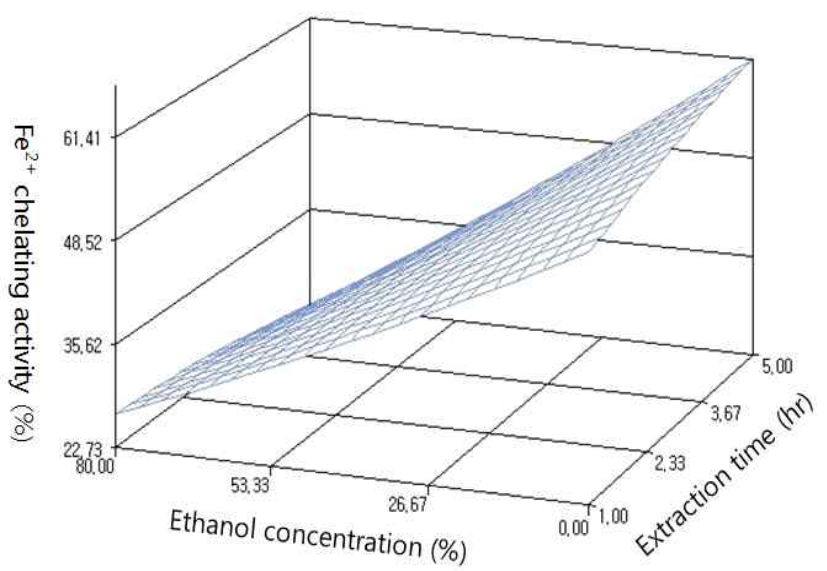

Fig. 4. Response surface for $\mathrm{Fe}^{2+}$ chelating activity of the dried Gugija as a function of extraction ethanol concentration and time.

\section{최적 추출조건 설정}

항산화 효과가 우수한 항산화 성분의 최적 추출조건을 얻고자 갈색도, 총 페놀성 화합물, $\mathrm{ABTS}$ 라디칼 소거능 및 $\mathrm{Fe}^{2+}$ chelating activity에 대한 등고선도를 겹쳐 그려 최적 조건을 설정하였다.(Fig. 5).
항산화 성분인 총 페놀성 화합물이 많이 추출되는 조건 은 에탄올 농도가 상대적으로 낮은 10 20\%에서 4 5 hr 추출하는 것으로 설정되었으며, 항산화 성분인 페놀성 화 합물이 높게 추출되고 $\mathrm{ABTS}$ 라디칼 소거능 및 $\mathrm{Fe}^{2+}$ chelating activity가 높은 조건으로 등고선도가 겹쳐지는 부 분을 최적 조건으로 설정하여 임의의 최적 조건(에탄올 농 도 $15 \%$ 및 추출 시간 $5 \mathrm{hr}$ )으로 항산화성이 높은 구기자 추출물을 얻었다.

임의의 최적 추출조건에서 추출된 추출물의 총 페놀성 화합물이 $2,397 \mu \mathrm{g}, \mathrm{ABTS}$ 라디칼 소거능이 $15.62 \%$ 그리고 $\mathrm{Fe}^{2+}$ chelating activity가 $54.78 \%$ 로서 증류수로 1 시간 추출 한 대조구(총 페놀성 화합물이 $1,293 \mu \mathrm{gg}, \mathrm{ABTS}$ 라디칼 소거 능이 $4.77 \%$ 그리고 $\mathrm{Fe}^{2+}$ chelating activity $\left.43.82 \%\right)$ 에 비해 증가된 항산화 성분 및 항산화 효과를 나타내었다.

이상의 연구 결과를 종합해 볼 때 항산화 효과가 우수한 총 페놀성 화합물, 금속 킬레이트 등 항산화 성분을 충분하 게 추출하기 위해서는 에탄올 10 20\%에서 4 5시간 추출하 는 것이 적당한 것으로 여겨진다.

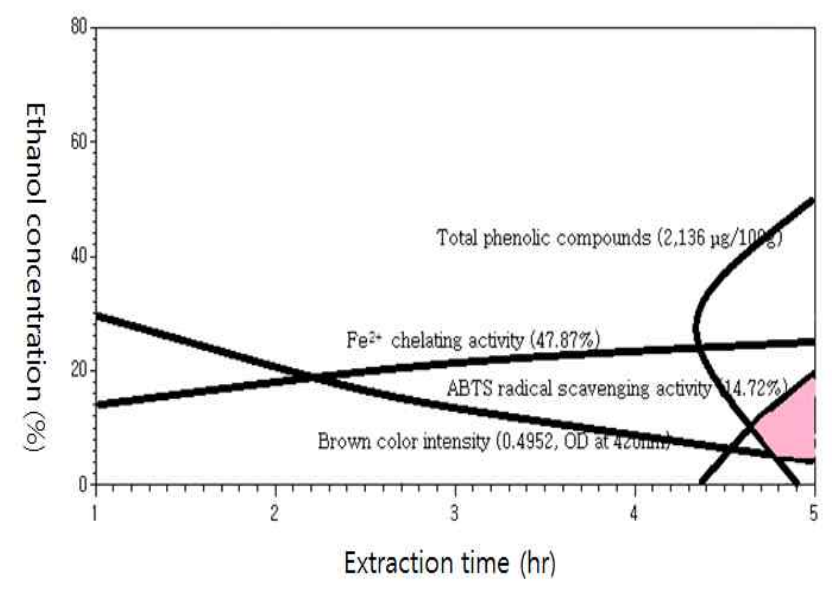

Fig. 5. Superimposed contour map of optimized condition for brown color intensity, total phenolic compounds, ABTS radical scavenging activity and $\mathrm{Fe}^{2+}$ chelating activity of the dried Gugija as a function of extraction ethanol concentration and time.

\section{요 약}

본 연구는 건조 구기자의 항산화 성분 추출을 최적화 하기 위한 추출 조건변수는 에탄올 농도 $\left(\mathrm{X}_{1}, 0 \sim 80 \%\right)$ 및 추출 시간 $\left(\mathrm{X}_{2}, 1 \sim 5 \mathrm{hr}\right)$ 이며, 종속변수로는 갈색도, 총 페놀성 화합물, $\mathrm{ABTS}$ 라디칼 소거능 및 $\mathrm{Fe}^{2+}$ chelating activity로 반응표면분석을 실시하였다. 갈색도, 총 페놀성 화합물, ABTS 라디칼 소거능 및 $\mathrm{Fe}^{2+}$ chelating activity에 대한 회귀 식의 $\mathrm{R}^{2}$ 은 각각 $0.8903,0.8667,0.8486,0.9214$ 로 5 10\%의 유의수준에서 유의성이 인정되었다. 건조 구기자 갈색도가 가장 높은 추출 조건은 에탄올 농도 $78.10 \%$ 에서 $2.38 \mathrm{hr}$ 
추출한 것( 0.75 , 흡광도)으로 나타났다. 총 페놀성 화합물이 가장 높은 추출 조건은 에탄올 농도 $30.17 \%$ 에서 $4.94 \mathrm{hr}$ 추출한 것 $(2,355 \mu \mathrm{g})$ 으로 나타났다. ABTS 라디칼 소거능이 가장 높은 추출 조건은 에탄올 농도 $16.21 \%$ 에서 $4.61 \mathrm{hr}$ 추출한 것(13.83\%)으로 나타났다. 그리고 $\mathrm{Fe}^{2+}$ chelating activity가 가장 높은 추출 조건은 에탄올 농도 $0.76 \%$ 에서 $3.39 \mathrm{hr}$ 추출한 것 $(58.54 \%)$ 으로 나타났다. 갈색도, 총 페놀 성 화합물, $\mathrm{ABTS}$ 라디칼 소거능 및 $\mathrm{Fe}^{2+}$ chelating activity에 대한 등고선도를 겹쳐 그려 얻은 최적 조건 (에탄올 농도 $15 \%$ 및 추출 시간 $5 \mathrm{hr}$ )으로 추출된 추출물의 총 페놀성 화합물은 2,397 $\mu \mathrm{g}$ 이었으며, $\mathrm{ABTS}$ 라디칼 소거능은 $15.62 \%$, 그리고 $\mathrm{Fe}^{2+}$ chelating activity는 $54.78 \%$ 로서 증류수 로 1시간 추출한 대조구(총 페놀성 화합물 1,293 $\mu \mathrm{g}$, ABTS 라디칼 소거능 $4.77 \%$ 및 $\mathrm{Fe}^{2+}$ chelating activity $43.82 \%$ )에 비해 항산화 성분이 많이 추출되어 우수한 항산화 효과를 나타내었다.

\section{감사의 글}

이 논문은 2016년 (재)청양군부자농촌지원센터 지원에 의하여 수행된 것으로 이에 감사를 드립니다.

\section{References}

1. Kim TJ (1996) Resource Plants in Korea III. Publishing Department of Seoul University, Korea, p 318-319

2. Park YJ, Kim MH, Bae SJ (2002) Enhancement of anticarcinogenic effect by combination of Lycii fructus with vitamin C. J Korean Soc Food Sci Nutr, 31, 143-148

3. Amagase H, Farmsworth NR (2011) A review of botanical characteristics, phytochemistry clinical relevance in efficacy and safety of Lycium barbarum fruit (Goji). Food Res Intl, 44, 1702-1717

4. Cho YJ, Chun SS, Cha WS, Park JH, Lee KH, Kim $\mathrm{JH}$, Kwon HJ, Yoon SJ (2005) Antioxidative and antihypertensive effects of Lycii fructus extracts. J Korean
Soc Food Sci Nutr, 34, 1308-1313

5. Park BH, Cho HS, Kim DH (2005) Antioxidative effects of solvent extracts of Lycii fructus Powder (LFP) and Maejakgwa made with LFP. J Korean Soc Food Sci Nutr, 34, 1314-1319

6. Park BH, Yang HH, CHo HS (2012) Quality characteristics and antioxidative effect of Yukwa prepared with Lycii fructus Powder. J Korean Soc Food Sci Nutr, 41, 745-751

7. Kang MH, Choi CS, Chung HK (2003) Physical properties and antioxidant activities of Lycii fructus beer. Korean J Food Culture, 18, 569-574

8. Chung HK, Choi CS, Yang EJ, Kang MH (2004) The effect of Lycii fructus beer intake on serum lipid profiles and antioxidant activity in rats. Korean J Food Culture, 19, 52-60

9. Choi YM, Kim MH, Shin JJ, Park JM, Lee JS (2003) The antioxidant activities of the some commercial teas. J Korean Soc Food Sci Nutr, 32, 723-727

10. Myers RH (1971) Response Surface Methodology. Allyn and Bacon Inc., Boston, USA. p 127-134

11. Dewanto V, Wu X, Adom KK, Liu RH (2002) Thermal processing enhances the nutritional values of tomatoes by increasing total antioxidant activity. J Agric Food Chem, 50, 3010-3014

12. Re R, Pellegrini N, Proteggente A, Pannala A, Yang M, Rice-Evans C (1999) Antioxidant activity applying an improved ABTS radical cation decolorization assay. Free Radic Biol Med, 26, 1231-1237

13. Hus B, Coupar IM, Ng K (2006) Antioxidant activity of hot water extract from the fruit of the Doum palm, Hyphaene thebaica. Food Chem, 98, 317-328

14. Oh SL, Kim SS, Min BY, Chung DH (1990) Composition of free sugars, free amino acids, non-volatile organic acids and tannins in the extracts of L. chinensis M., A. acutiloba K., S. chinensis B. and A. sessilifforum S. Korean J Food Sci Technol, 22, 76-81 